\title{
Political Parties and Clientelism in Southeast Asia
}

\author{
Ward Berenschot \\ KITLV/Royal Netherlands Institute of Southeast Asian and Caribbean Studies \\ Berenschot@kitlv.nl
}

Tomsa, D., \& Ufen, A. (eds), Party politics in Southeast Asia. Clientelism and electoral Competition in Indonesia, Thailand and the Philippines. Milton Park: Routledge, 2012, xix + 222 pp. ISBN 9780415519427. Price: GBP: 140.00 (hardback).

Mietzner, Marcus. Money, Power, and Ideology. Political Parties in post-authoritarian Indonesia. Honolulu: University of Hawai'i Press, 2013, xxiv +301 pp. IS BN 9780824839602. [Asian Studies Association of Australia, Southeast Asian Publications Series]. Price: USD 35.00 (paperback).

If one would have to pick a single word to describe the nature of Southeast Asian politics, then 'clientelism' would be a good contender-with perhaps 'oligarchy' as a close runner-up. The study of political clientelism-the practice of exchanging a personalized, non-policy based access to money and state resources for electoral support - has a long and venerable history in the study of Southeast Asian polities. Democratization processes have lent this history a new chapter: democratic elections from Indonesia, the Philippines to Cambodia and Thailand have fostered an enthusiastic adoption of vote buying or selective distribution of state resources as means to garner electoral support. 'Money politics' often trumps ideology, and personal, clientelistic networks trump party discipline. The pervasiveness of clientelistic exchanges is posing considerable challenges for political parties, in various ways: vote buying is depleting their coffers, clientelistic clans foster factionalism, and shady deals with corporate campaign donors are undermining their popularity.

Political clientelism also poses considerable challenges for the study of political parties. From Duverger's early classic (1959) onwards, much of the literature on political parties implicitly assume political parties to 'programmatic', inferring that they compete for the voter's favour by offering a program of ideas and policy proposals. This literature hardly offers a systematic study of political par-

(C) WARD BERENSCHOT, 2015 | DOI: 10.1163/22134379-17104007

This is an open access article distributed under the terms of the Creative Commons 
ties that largely —or partly, as parties often mix strategies—attract voters by offering personal favours like jobs, money, or access to public services. When such parties do get mentioned, they are often discussed in comparison with programmatic parties, as not-yet-programmatic parties. As a result the western literature on political parties and their focus on competition in a 'marketplace of ideas' is somewhat unsatisfying for those wanting to understand and compare parties in Southeast Asia—or, for that matter, South Asia, Africa, or South America. Isn't it possible to study clientelistic political parties in their own right, using theoretical frameworks that are not derived from American or European experiences of state and party building?

Two recent books on political parties in Indonesia, the Philippines and Thailand illustrate the importance and the challenges involved in the study of clientelistic political parties. The books not only illustrate differences of opinions among scholars - which, in itself, is merely a sign of lively, healthy academic debate-but also the difficulties of finding appropriate theoretical frameworks to study political parties that are simply not very interested in doing what they are supposed to do, namely translating societal demands into policies and laws. Yes, political parties engage in such programmatic politics, too-particularly in the form of populist policies that provide subsidized healthcare, education and other subsidies to the poor. But political parties in these countries mix such electoral appeals - in varying ratios - with the personalized, clientelistic distribution of money and state resources through complex networks of brokers. How can we understand the different forms this clientelistic politics takes, why it takes these forms, and what effects has it on the organization and functioning of political parties?

The value of Party Politics in Southeast Asia, the edited volume that Dirk Tomsa and Andres Ufen put together lies in the way in which its essays stimulate reflection on the similarities and differences between political parties in Thailand, the Philippines and Indonesia. One of the recurring themes in the essays is the argument that political clientelism fosters organizational shallowness of political parties and, as Paige Tan argues, anti-party attitudes. In this book we read how in the Philippines political parties are merely a front for its constituting clans and 'clientelist clusters' that often switch party loyalty (Teehankee). We read how local party organizations in Thailand are largely absent (Sirivunnabood) and dependent on personal networks of 'chao pho' or local bosses (Bjarnegard). Even Indonesia parties, considered relatively more institutionalized, are weakening. After the country adopted direct elections for governors and district heads (and, in 2008 an open-list system of proportional representation for legislative elections), political parties have become more dependent on the charisma, funds, and networks of individual candidates 
(Tomsa). Clientelism is strengthening individual political careers, but not parties. As a result, the role of ideology and old socio-cultural milieus (aliran) in determining vote choice seems to be weakening (Ufen).

This is where Marcus Mietzner's book, Money, Power, and Ideology: Political parties in Post-Authoritarian Indonesia, (partly) disagrees. Based on fifteen years of research experience, Mietzner similarly uses instructive and illuminating comparisons with other countries to make the case that Indonesia's political parties are actually not doing so badly. Yes, they face acute financing problems, which gets them into all sorts of unsavory relations. But other that, Mietzner argues, parties are relatively well institutionalized, rooted in society and reasonably competitive. Furthermore, socio-political milieus do still structure Indonesia's party system and voters are thus not only seduced by clientelistic appeals. Given the gloomy tones in which Indonesia's parties are usually discussed, Mietzners arguments are refreshing and stimulating. Using a wealth of interview material and a firm, detailed grasp of the history of the country's political system, the book is highly recommended for anyone wishing to get an inside view of Indonesia's politics.

Yet there is something unsatisfactory about Mietzner's approach and argumentation. This stems largely from his usage of two (originally western) theoretical frameworks for the study of political parties, party institutionalization and party cartelization. While Mietzner is at times highly critical of these approaches, they still structure his book. This unhappy marriage underscores the need to develop and apply alternative theoretical frameworks more attuned to the study of clientelistic political arenas. Take, for example, Mietzner's argument that Indonesia's parties are reasonably well institutionalized. Mietzner substantiates this claim by applying, comparatively, often-used criteria like electoral volatility, party identification, party endurance and the 'rootedness in society' of political parties. Because political parties in Indonesia have a comparatively stable vote share, are old, and have strong links with societal organizations, Mietzner can argue that Indonesia's parties are 'structurally strong organizations'. Voter identification with parties is going down, but in a manner on par with other democracies.

Yet these criteria, derived from the literature on party institutionalization, seem most relevant for the study of western, largely programmatic, democracies. They pay little attention to other dimensions of party institutionalization that can perhaps be taken for granted in more programmatic political arenas, such as the control of parties over candidate selection, the involvement of party members in election campaigns, or the control of political parties over the personalized distribution of state resources. That is what parties do: the literature generally simply assumes that parties select candidates and campaign for 
them. And the third dimension is simply irrelevant for non-clientelistic political parties.

Yet in the context of a largely clientelistic political arena, these three dimensions should not be ignored. As Mietzner does mention, parties in Indonesia rarely appoint figures from the party cadre as candidates for district heads and governors, as moneyed outsiders often take the lead in building (read: buying) a coalition of parties. Furthermore, these candidates generally only rely only in a limited way on party cadre for their election campaigns, as they are generally run by individual campaign teams (called 'tim sukses'), consisting of a mix of personal friends, local influentials, and various wannabe brokers. This prominence of 'tim sukses' is partly due to the perception that political parties have only limited mobilizational strength.

Their limited mobilizational strength is partly due to another important comparative dimension, the control of political parties over the distribution of state resources. This seems to vary across Southeast Asia. Almost in passing, Bjarnegard mentions in her essay in Tomsa and Ufen's book the role of Thai political parties in arranging drainage, roads, electricity, and admission in school for their supporters. 'We help people get what they ask for' (p. 148). This kind of 'constituency service' resonates with, for example, Auyero's description (2001) of the everyday political mediation that Argentine's Peronist party engages in, maintaining an extensive network of 'unidades basicas' to distribute state-funded aid to the poor. There are some hints in Thomson's and Teehankee's essays in Tomsa and Ufen's book that constituency service does play some role in the interaction between parties and voters interaction in the Philippines. Yet the book as a whole, like Mietzner's, largely misses this comparative dimension.

That is regrettable, as the degree of party control over the distribution of state resources seems to constitute an important contrast with Indonesia. In Indonesia, political parties are not only largely absent at the local levelit is an often-heard complaint that political parties are not seen in between elections - but they are also hardly involved in the kind of constituency service that Bjarnegard and Auyero describe. An important legacy of Indonesia's authoritarian past is that the bureaucracy has maintained considerable discretionary control over the distribution of state resources. Indonesians go to local state representatives (village heads, neighbourhood heads, lurah, camat) to arrange the things that Bjarnegard describes. Their prominence and influence can be observed during election campaigns: while officially forbidden, candidates often rely on these local state representatives to campaign for them. State representatives are generally considered more influential than party members because their relatively strong control over the distribution of state resources 
enables them to accumulate feelings of gratitude and indebtedness. This contrasts sharply with Auyero's description of local politics in Argentina, suggesting that where parties have developed a stronger grip over the distribution of state resources, this kind of gratitude (and, subsequently, votes) can be accumulated by political parties.

This contrast further underscores the importance of going beyond dichotomies between 'clientelistic parties' and 'programmatic parties'. Particularly when the latter is, for example in Hamayotsu's contribution, conceptualized as 'well-institutionalised parties', coming with unfounded and unrealistic expectation that 'non-clientelistic' religious parties would fare better during elections. Such dichotomies bring us back to using an idealized programmatic party as a measuring stick. What is needed, instead, is to develop theory that enables us to compare between clientelistic political parties, and focus attention on the different ways that clientelistic interactions between parties and voters may take. The observations on Indonesian parties above-parties rarely promote their own cadre, they play limited role in election campaigns, are considered to have limited mobilizational strength, and hardly engage in constituency service-should form the core, not the periphery, of an assessment of the relative strength of political parties. If we compare Indonesian parties on these dimensions, Mietzner's conclusion that Indonesia's parties are relatively strong and well institutionalized appears unfounded. Such an attention to the nature of clientelistic exchange could also serve to assess Mietzner's assumption that if Indonesians vote in accordance with their socio-cultural background (aliran), this must mean they vote in an ideological, non-clientelistic manner. That need not be the case: the continued importance of aliran might also be due to the fact that religious organizations like $\mathrm{NU}$ or Muhammadiyah constitute influential clientelistic networks capable of facilitating clientelistic exchanges in areas where they are strong.

The study of clientelistic political parties also involves a methodological challenge. Research is needed that can uncover the concrete forms that voterparty (or party-politician) exchanges may take. It is telling that in Tomsa and Ufen's book, no essay - apart from Bjarnegard's - contains any quotes from informants. These essays largely engage in a more helicopter-view-type of party politics. Such general analysis - while useful - tempts the researcher to focus on the more easily generalizable, visible, and formal aspects of politics, at the expense of attention for the more shadowy and less visible nature of clientelistic interactions. Mietzner's book, in contrast, is richly illustrated with telling quotes from party representatives. Yet the underlying research also largely focusses on national-level party operatives and national party conferences. This focus on high-level politics has precluded attention for the exact role of 
political parties in more shadowy processes such as candidate selection or the facilitation of state-citizen interaction. It is not surprising then, that the abovementioned dimensions receive relatively little attention.

On the whole, with their comparative analyses these books constitute important steps forward in the study of political parties in democratizing Southeast Asia. These books also suggest the work that lies ahead: the development of theoretical frameworks more suitable for studying largely clientelistic political parties, and the integration of more close-up, ethnographic research methods.

\section{References}

Duverger, Maurice (1959). Political parties. Their organization and activity in the modern state. London: Methuen.

Auyero, Javier (2001). Poor people's politics. Peronist survival networks and the legacy of Evita. Durham: Duke University Press, 2001. 